\title{
Amperometric Hydrogen Peroxide Biosensor Based on Horseradish Peroxidase Entrapped in Titania Sol-Gel Film on Screen-Printed Electrode
}

\author{
Reza E. Sabzi ${ }^{1,2}$, Fereshteh Rasouli ${ }^{1}$, Farshad Kheiri ${ }^{3}$ \\ ${ }^{1}$ Department of Chemistry, Faculty of Science, Urmia University, Urmia, Iran \\ ${ }^{2}$ Institute of Biotechnology, Urmia University, Urmia, Iran \\ ${ }^{3}$ Department of Chemical Engineering, Urmia University of Technology, Urmia, Iran \\ Email: rezasabzi@yahoo.com
}

Received August 23, 2013; revised September 23, 2013; accepted October 15, 2013

Copyright (C) 2013 Reza E. Sabzi et al. This is an open access article distributed under the Creative Commons Attribution License, which permits unrestricted use, distribution, and reproduction in any medium, provided the original work is properly cited.

\begin{abstract}
We report the fabrication of disposable and flexible Screen-Printed Electrodes (SPEs). This new type of screen-printed electrochemical platform consists of Ag nanoparticles (AgNPs) and graphite composite. For this purpose, silver nanoparticles were first synthesized by a chemical reduction method. The morphology and structure of the AgNPs were analyzed using a Scanning Electron Microscope (SEM) and UV-Visible spectroscopy. Graphite was chosen as the working electrode material for the fabrication of a thick-film. The fabrication of a screen-printed hydrogen peroxide biosensor consisting of three electrodes on a polyethylene terephthalate (PET) substrate was performed with a spraying approach (working, counter and reference: enzyme electrode, graphite, pseudo reference: $\mathrm{Ag} / \mathrm{AgCl}$ ). This biosensor was fabricated by immobilizing the peroxidase enzyme (HRP) in a Titania sol-gel membrane which was obtained through a vapor deposition method. The biosensor had electrocatalytic activity in the reduction of $\mathrm{H}_{2} \mathrm{O}_{2}$ with linear dependence on $\mathrm{H}_{2} \mathrm{O}_{2}$ concentration in the range of $10^{-5}$ to $10^{-3} \mathrm{M}$; the detection limit was $4.5 \times 10^{-6} \mathrm{M}$.
\end{abstract}

Keywords: Screen-Printed Electrode; Ag Nanoparticle; Titania Sol-Gel; Biosensor

\section{Introduction}

Hydrogen peroxide is a reactive oxygen species [1] and is the simplest peroxide which has a higher capability of oxidation. This molecule is a by-product of several oxidative-biological reactions which are the main factors of diseases such as asthma, cancer, neurodegenerative disorders, heart disease, etc. [2-7]. It acts as an important mediator in environmental, pharmaceutical, clinical, industry, food analyses and medicine production [8-10]. Its determination based on a simple, credible, precise, fast and economical method is very important. In order to assay hydrogen peroxide, several techniques have been applied, including chemiluminesence, Voltammetry, spectrometry, fluorimetry, and an electrochemical biosensor [11-15]. Most of these methods, however, had disadvantages, such as complexity, high cost, time consumption, the need to use expensive reagents, and the existence of interference [16,17], which act as hindrances to the accurate determination of hydrogen peroxide. Additionally, the validity of most of these methods may be under question. Taking all the above-mentioned shortages into consideration, it can be said that electrochemical biosensing methods which are based on enzyme electrodes not only do not have the deficiencies of previous methods, but also enjoy advantages such as high levels of sensibility, selectivity, fast analysis, low consumption of reagents, low volume of analyte usage, and easy design and application $[18,19]$. Recently, some inventive techniques for the fabrication of sensors have been proposed: thick-and thin-film technology, silicon technology, etc. Among these, the equipment needed for thick-film technology is the most convenient and cheapest, and therefore, is the most applicable method for sensor production. The thick-film technique can be defined as the sediment of ink on a substrate surface with their pattern and thickness controlled principally by screen-printing [20]. Screen-printing, as a subset of thickfilm technology, is flexible and versatile and provides the possibility of form and size selection. Screen-printed electrodes (SPE) are miniaturized tools constructed by 
printing multiple successive layers of different compounds, such as conductive carbon ink and various metal pastes, onto various substrates, such as alumina, ceramic, polyvinyl chloride (PVC), gold, and iron $[21,22]$. Due to their mechanical and electrochemical stability, these electrodes are good alternatives for classical electrodes. Their disposable feature also resolves the problem of pollution caused by previous tests. Based on the previous extensive studies, an essential principle of the development of SPE thick-film biosensors is enzyme immobilization $[23,24]$. Several methods for this have been investigated, for example, adsorption, cross linking, using solgel matrixes, and entrapment with polymer [25-29]. Despite these studies, there are many problems concerning simplification of fabrication, correct maintenance of enzymes on the biosensor surface, maintaining its activity, and ultimately increasing the life of the biosensors. Most of these techniques can be used simply, but due to the weak binding of enzyme to substrate, some enzymes permeate from its surface. Moreover, covalent techniques are boring and require several chemical steps [30]. On the other hand, because of their unique advantages, including preparation at low temperatures, chemical inertness, tunable porosity, low leakage of materials, and thermal stability, sol-gel methods have been extensively developed [31,32]. Sol-gel methods in low temperatures and through hydrolysis and poly-condensation of an appropriate precursor such as $\mathrm{TiO}_{2}, \mathrm{SiO}_{2}$ create a three-dimensional inorganic network $[33,34]$. Common features of a sol-gel matrix are porosity, surface area, polarity, and stability which are dependent on the process of hydrolysis progression and condensation [31]. Several methods such as spin-coating, drop-coating, radio frequency sputtering, and chemical vapor deposition (CVD) are practical for forming an active layer on the membrane's surface [35]. Among these methods, CVD is a chemical process during which the substrate is exposed, for a specific time, to the evaporation of one or several precursors. In this situation, sediment is formed on the surface of the substrate by the precursor or reacts to it. Recently, with the use of a new vapor deposition process, Titania sol-gel is produced [36-38]. This method is simple and an easier control of the chemical composition of layers than other methods. It is also immune to the shortcoming that is created by the acidic catalyst and calcinations step needed in the traditional Titania sol-gel process [39-41]. The enzyme, as a biocatalyst, loses its ability without the existence of water, and no response can be seen in this condition. Then Titania sol-gel membranes maintain water that is stored within the adjacent layers of enzyme [42]. In this work, we attempted to report on a novel platform based on flexible polyethylene terephthalate
(PET) substrate in order to design a high-performance electrochemical screen-printed biosensor. Due to the usage of a self-assembly technique and a flexible polymer substrate, the cost of the biosensor is very competitive. In this research a simple and controllable vapor deposition method was used to prepare a novel horseradish peroxidase (HRP) that entrapped Titania sol-gel film on the surface of graphite composite sprayed onto a flexible surface of polyethylene terephthalate (PET) substrate modified with silver nanoparticles (Ag NPs)poly (vinyl chloride) (PVC) nanocomposite as a silver paste. In the mentioned process, graphite composite was chosen due to its electrochemical properties, low background current, and wide potential window. Ag nanoparticles exhibit the highest electrical and thermal conductivity. The conductivity of Ag nanoparticles is a very important factor; therefore, in order to achieve good step coverage and to decrease the resistance scale, it is necessary to control the percentage ratio of $\mathrm{Ag}$ nanoparticles to PVC. Based on the findings of recent studies, the designed HRP/Titania sol-gel/graphite membrane systems provide a biocompatible support for enzyme molecules to efficiently retain their good activity and an opportunity to construct a sensitive amperometric hydrogen peroxide screen-printed biosensor.

\section{Experiment}

\subsection{Reagents and Chemicals}

Horseradish peroxidase (HRP) was obtained from Sigma Corp. (USA), used without purification, tetra-n-butyl orthotitanate (TBT), hydrogen peroxide (30\%); high purity graphite powder, poly (vinyl chloride) and tetrahydrofuran (THF) were purchased from Merck. Background electrolytes for electrochemical experiments were $0.1 \mathrm{~mol} \cdot \mathrm{L}^{-1}$ phosphate buffer solutions (PBS) containing $0.1 \mathrm{~mol} \cdot \mathrm{L}^{-1} \mathrm{KCl}$. All other chemicals were of analytical grade and were used without further purification. All solutions were made up with distilled water.

\subsection{Apparatus}

The electrochemical measurements were performed at room temperature in a conventional one-compartment cell with a three-electrode system consisting of an enzyme electrode as the working electrode, a graphite as the counter electrode, and an $\mathrm{Ag} / \mathrm{AgCl}(0.1 \mathrm{M} \mathrm{KCl})$ as the pseudo-reference electrode. Cyclic voltammetric experiments were carried out in a static electrochemical cell at $25^{\circ} \mathrm{C}$, while amperometric experiments were carried out in a stirred cell with a successive addition of hydrogen peroxide solution to the cell by applying an optimum potential to the working electrode. These measurements were performed with a $\mu$-Autolab Type II 
potentiostat (EcoChemie B.V, Ultrecht, The Netherlands) controlled by the Autolab GPES software version 4.9. A freeze dryer (FD-550, Tokyo Rikakikai Co., Ltd.; Tokyo, Japan) was used to remove water from the resultant nanoparticles.

\subsection{Synthesis of Silver Nanoparticles}

Ag nanoparticles are provided based on following method: Firstly $600 \mathrm{~mL}$ solution of $0.01 \mathrm{M} \mathrm{NaBH}_{4}$ and tri-sodium citrate $\left(\mathrm{C}_{6} \mathrm{H}_{5} \mathrm{O}_{7} \mathrm{Na}_{3}\right)$ was provided, Then this solution was titrated with $200 \mathrm{~mL}$ solution of $0.01 \mathrm{M}$ $\mathrm{AgNo}_{3}$ while being stirred and temperature controlled. After that, a yellow solution was obtained which approved the formation of silver nanoparticles. Finally it was dried in a freeze dryer for about $24 \mathrm{~h}$ to remove the water from the resultant nanoparticles.

\subsection{Preparation of Screen-Printed Electrodes}

Screen-printed electrodes consisted of three printed electrodes: an $\mathrm{Ag} / \mathrm{AgCl}$ pseudo-reference electrode and two graphite electrodes acting as working and counter electrodes. The size of each electrode set was $1.5 \times 3 \mathrm{~cm}$. The procedures used for the construction of the screenprinted electrodes are shown in Figure 1. In the primary stage, the forms of the mentioned electrodes were designed separately (in the beginning stage working electrode and then pseudo-reference and counter electrodes) by template on two PET. It is necessary to point out that this was designed in order to prevent the deposition of Titania sol-gel (used to immobilize the enzyme applied in constructing the biosensor discussed in the following Section 2.5) on the surface of the pseudo-reference and counter electrodes. Then the dispersed solution of silver nanoparticles and PVC (95:5\%) in the THF solvent was sprayed on the surface of the designed electrodes. This constructed layer supplied the conductivity character of our electrode system. In the next phase, a compound solution of graphite and PVC (97:3\%) was sprayed on the part of the modified surface with silver nanoparticles

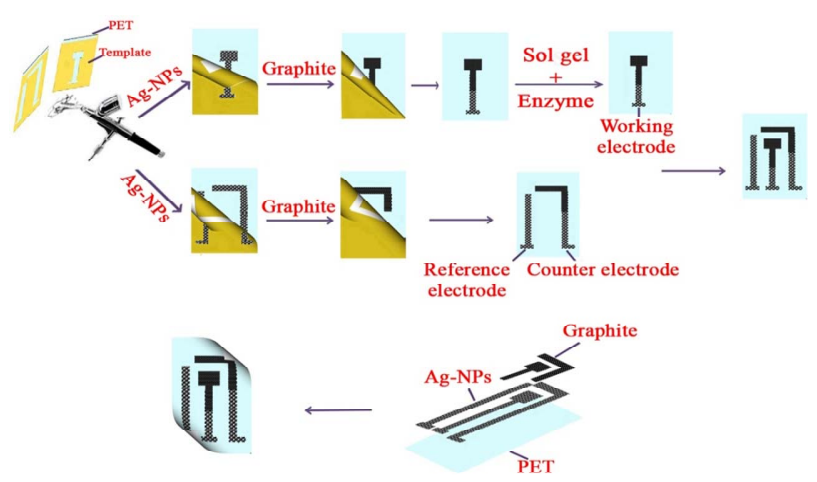

Figure 1. Schematic diagrams detailing the fabrication steps of a screen-printed electrode. in working and counter electrodes. In order to eliminate the remaining solvent used in producing compounds, the produced film was cooked about 30 minutes at a temperature of $60^{\circ} \mathrm{C}$. The pseudo-reference electrode was made by deposing the $\mathrm{Cl}^{-}$ion via placing an electrode modified with NPs in $\mathrm{KCl}$ solution and potential $(0,1) \mathrm{V}$ applied for 10 seconds. Finally after the enzyme was immobilized on the working electrode's surface (Section 2.5), the manufactured electrodes were applied to determine hydrogen peroxide as a three electrode system.

\subsection{Preparation of Enzyme Electrode (Biosensor)}

The HRP enzyme solution was first obtained by dissolving $5 \mathrm{mg}$ HRP in $5 \mathrm{~mL} 0.1 \mathrm{M}$ PBS (pH 7.0). $10 \mu \mathrm{L}$. The HRP solution was dropped onto the surface of the screenprinted working electrode pretreated as previously explained in this study. The electrode was then suspended vertically above tetra-n-butyl orthotitanate in a sealed flask and kept at a constant temperature of $25^{\circ} \mathrm{C}$ for $6 \mathrm{~h}$. This resulted in the absorption of saturate tetra-n-butyl orthotitanate vapor at $25^{\circ} \mathrm{C}$ by the enzyme solution and the slow formation of a Titania sol-gel membrane through the hydrolysis of tetra-n-butyl orthotitanate on the surface, trapping the HRP in the membrane to produce an HRP/Titania sol-gel modified electrode. Finally, the biosensor was immersed in a $\mathrm{pH} 7.0$ phosphate buffer and kept at $4^{\circ} \mathrm{C}$ overnight to remove the excess enzyme from the electrode surface. The biosensor was stored in a $\mathrm{pH}$ 7.0 phosphate buffer at $4^{\circ} \mathrm{C}$ when it was not being used.

\section{Results and Discussion}

\subsection{Characterization of Silver Nanoparticles}

Metal nanoparticles include free electrons, which give surface plasmon resonance (SPR) absorption band, due to the combined vibration of metal nanoparticle electrons in resonance with light waves [43]. By increasing the time period of the aqueous component, the intensity of the absorption band increases and consequently the color changes from colorless to reddish-yellow. These characteristic color changes are caused by the excitation of the surface plasmon resonance in the metal nanoparticles (Figure 2). (Inset A) shows the UV-Vis spectra of the synthesized Ag nanoparticle solution in the wavelength range of 300 to $800 \mathrm{~nm}$. A characteristic peak at $412 \mathrm{~nm}$ is clearly observed, which is indicative of the formation of $\mathrm{Ag}$ nanoparticles. SEM is a powerful tool that provides an image of surface details and produces the signals represent of information on the surface topography, composition, and other properties [44]. The SEM image of AgNPs is shown in Figure 2 (Inset B). It can be seen from the image that the AgNPs tend to form clusters and that the diameter of one single AgNPs ranges from 62 to 


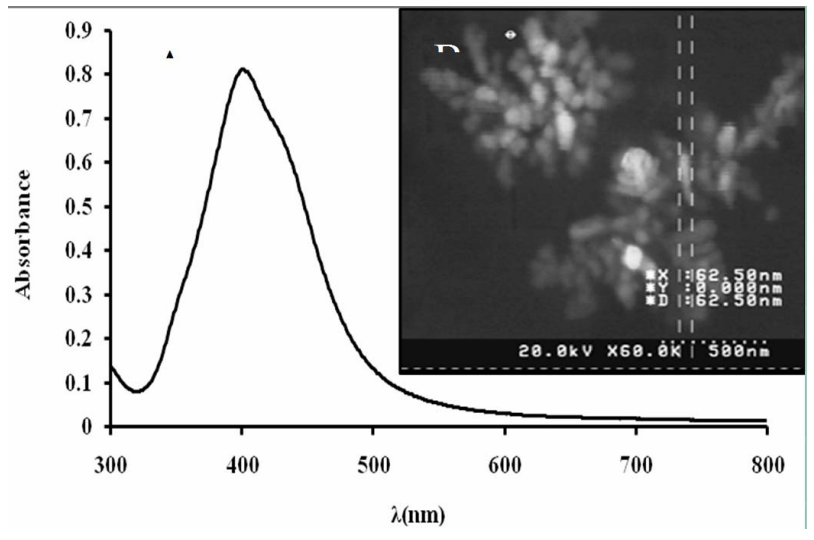

Figure 2. UV-absorption spectra (inset A) and SEM image (inset B) obtained for synthesis of AgNPs solution.

$84 \mathrm{~nm}$.

\subsection{Optimization of Value of Ag Nanoparticles and Graphite in Screen-Printed Electrodes}

In order to fabricate screen-printed electrodes with high conductivity while simultaneously remaining stable, diffe-rent percentages of Ag nanoparticles, PVC, and graphite were examined. Observations are presented in the following sections. Silver nanoparticles and PVC were in (80:20 wt $\%),(85: 15 \mathrm{wt} \%),(95: 5 \mathrm{wt} \%)$ and $(98: 2 \mathrm{wt} \%)$ with levels of resistance of $130,40,7$, and $6 \Omega \mathrm{cm}^{-2}$ respectively. It should be said that despite the increased conductivity caused by the increased $\mathrm{Ag}$ nanoparticles, adherence in (98:2 wt\%) was low; therefore, with regard to the two limiting factors of conductivity and adherence, (95:5 wt\%) from Ag nanoparticles and PVC were selected. Graphite and PVC solution was sprayed on a surface modified with Ag nanoparticles with percentages of (85:15 wt\%), (95:5 wt\%), (97:3 wt\%), and (99:1 wt\%), that ultimately acquired resistant levels of $300,60,20$ and $14 \Omega \cdot \mathrm{cm}^{-2}$ respectively. Because $(99: 1 \mathrm{wt} \%)$ had a low level of adherence, $(97: 3 \mathrm{wt} \%)$ from graphite and PVC were selected.

\subsection{Study of Coductivity of Modified Screen-Printed Electrodes by Cyclic Voltametry}

Potassium hexacyanoferrate (III) is mainly selected as a model for characterizing electrochemical systems in aqueous solutions [45]. A valuble and convenient tool to monitor the characteristics of surface-modified electrodes is the cyclic voltametry of ferro/ferricyanide redox couple [46]. CV was conducted in $5 \mathrm{mM} \mathrm{Fe}(\mathrm{CN})_{6}{ }^{3-/ 4-}$ and $0.1 \mathrm{M} \mathrm{KCl}$ at $100 \mathrm{mV} \mathrm{s}^{-1}$ for a surface modified with the optimum percentage of AgNPs to PVC (95:5\%) and different percentages of graphite powder. Figure 3 compares the current response at each stage of the fabrication process. As shown in Figure 3, curve C, the fabricated

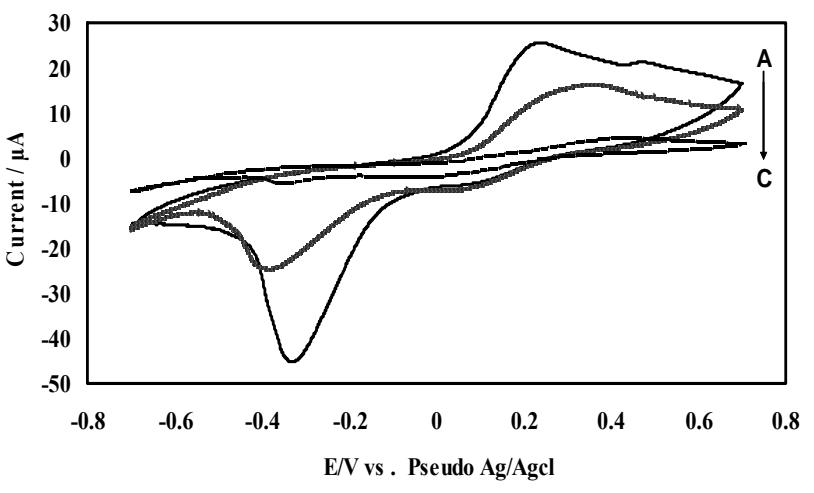

Figure 3. Cyclic voltammograms of modified electrodes with PVC and graphite. A: 3\% PVC + 97\% graphite B: 5\% PVC + 95\% graphite C: $15 \%$ PVC $+85 \%$ graphite. All results were obtained in a $5 \mathrm{mM} \mathrm{Fe}(\mathrm{CN})_{6}{ }^{3-/ 4-}$ solution (PBS, 0.1 M, pH 7.0), with the supporting electrolyte $\mathrm{KCl}(0.1 \mathrm{M})$, and optimum percentage of AgNPs to PVC (95:5\%).

electrode with 85 wt.\% graphite showed a very small signal response towards the $\mathrm{Fe}^{\mathrm{III}} / \mathrm{Fe}^{\mathrm{II}}$ redox couple. PVC produced an insulating layer on the electrode that acted as a barrier to the electron transfer between $\mathrm{Fe}^{\mathrm{III}} / \mathrm{Fe}^{\mathrm{II}}$ and the surface modified with AgNPs, decreasing the anodic and cathodic currents, but the redox probe of $\mathrm{Fe}(\mathrm{CN})_{6}{ }^{3-14}$ revealed a reversible cyclic voltammogram with $95 \mathrm{wt} \%$ graphite (Figure 3, curve B). When spraying the 3\% PVC $+97 \%$ graphite composite onto the PET surface modified with AgNPs to PVC (95:5\%), a remarkable increase in current was observed (Figure 3, curve A). This was due to the fact that the increase in percentage of graphite markedly promoted the electron transfer of the analyte and the electrode surface and hence increased the current response.

\subsection{Electrocatalytic Behavior of HRP Titania Sol-Gel/Graphite Biosensor}

Figure 4, inset (A) (curves a-e) shows the cyclic voltammetric behavior of the biosensor in the absence of $\mathrm{H}_{2} \mathrm{O}_{2}$ and in the presence of $1 \times 10^{-5}-1 \times 10^{-3} \mathrm{M}$ hydrogen peroxide in PBS solution at a scan rate of $20 \mathrm{mV} \mathrm{s}^{-1}$. As seen in Figure 4 (curve a), no peak current appeared at the $\mathrm{CV}$ curve of the biosensor in the absence of $\mathrm{H}_{2} \mathrm{O}_{2}$. Also shown in Figure 4 (curves b-d), the cathodic peak current increased dramatically upon the addition of $1 \times$ $10^{-5}-1 \times 10^{-3} \mathrm{M}$ concentration of $\mathrm{H}_{2} \mathrm{O}_{2}$ at the surface of the biosensor, which can be ascribed to the electrochemical reaction of the immobilized HRP. Figure 4, inset (B) show calibration curve of biosensor, as can be seen The response was proportional to the concentration of hydrogen peroxide in the ranges of $0.01 \mathrm{mmol} \cdot \mathrm{L}^{-1}$ to $1.00 \mathrm{mmol} \cdot \mathrm{L}^{-1}$, while the detection limit was estimated to be $4.5 \mu \mathrm{mol} \cdot \mathrm{L}^{-1}$ at a signal to noise ratio of 3 . Based on experimental results, the catalytic current is mainly based on the electron transfer between HRP and the electrode, 


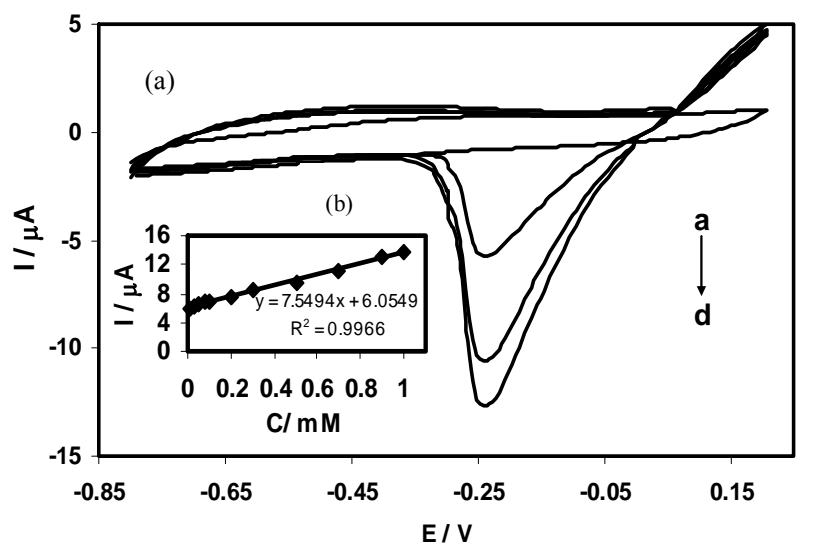

Figure 4. Inset (A), Cyclic voltammograms of the HRP/ titania sol-gel/graphite biosensor without (a) and with $1 \times$ $10^{-5}$ (b), $1 \times 10^{-4}$ (c) and $1 \times 10^{-3} \mathrm{~mol} \cdot \mathrm{L}^{-1}$ (d) $\mathrm{H}_{2} \mathrm{O}_{2}$. Inset (B), Calibration curve in the range of $1 \times 10^{-5}$ to $1 \times 10^{-3} \mathrm{M}$ of $\mathrm{H}_{2} \mathrm{O}_{2}$ concentration. Scan rate $20 \mathrm{mV} \cdot \mathrm{s}^{-1}$ vs. pseudo $\mathrm{Ag} /$ $\mathrm{AgCl}$ in a phosphate buffer $\mathrm{pH}$ 7.0, containing $0.1 \mathrm{M} \mathrm{KCl}$.

and the graphite membrane acts as a bridge providing an electrical contact or pathway for electron transfer between the immobilized HRP and the base electrode (AgNPs/PVC nanocomposite). The following Equations (1)-(3) explain the electrocatalytic reduction mechanism of HRP toward $\mathrm{H}_{2} \mathrm{O}_{2}$. HRP, as an oxidative hemecontaining enzyme, cleaves to the $\mathrm{O}-\mathrm{O}$ bond of hydrogen peroxide to form a first intermediate (compound I), which is an unstable two-equivalent oxidized form containing an oxyferryl heme and a porphyrin cation radical, Compound II is the second intermediate from the first reduction of the porphyrin radical cation, which retains the heme in the ferryl state $[47,48]$.

$$
\begin{gathered}
\mathrm{HRP}\left(\mathrm{Fe}^{3+}\right)+\mathrm{H}_{2} \mathrm{O}_{2} \rightarrow \text { Compound } \mathrm{I}\left(\mathrm{Fe}^{4+}=\mathrm{O}\right)+\mathrm{H}_{2} \mathrm{O} \\
\text { Compound } \mathrm{I}\left(\mathrm{Fe}^{4+}=\mathrm{O}\right)+\mathrm{e}^{-}+\mathrm{H}^{+} \rightarrow \mathrm{Compound} \mathrm{II}^{3} \\
\text { Compound } \mathrm{II}+\mathrm{e}^{-}+\mathrm{H}^{+} \rightarrow \mathrm{HRP}\left(\mathrm{Fe}^{3+}\right)+\mathrm{H}_{2} \mathrm{O}
\end{gathered}
$$

\subsection{Effect of Operational Conditions on the Biosensor Response}

Various operational conditions such as $\mathrm{pH}$, operating potential, and temperature can affect the biosensor response. The peroxidases are $\mathrm{pH}$-dependent enzymes and exhibit their maximum activities at different $\mathrm{pH}$ values [49]. On the other hand, the ability of amino acids presented at the active sites of the enzyme to interact with the substrate depends on their electrostatic state, which in turn depends on the $\mathrm{pH}$ of the solution; thus optimization of the working $\mathrm{pH}$ for the enzyme electrode is considered to be important [50]. The ionization states of the charged groups of enzymes that retained their ionizations from the last solution to which they have been exposed are influenced by the $\mathrm{pH}$ value of the last aqueous solution
[42]. The dependence of the biosensor response on $\mathrm{pH}$ of the measurement solution was investigated. A range of $\mathrm{pH}$ values between 4.0 to 9.0 was studied. Figure 5 depicts the response increase from $\mathrm{pH} 4.0$ and the increase of the buffer $\mathrm{pH}$ which led to a decrease in response, indicating that the catalytic response was controlled by the enzymatic activity. A decrease of enzymatic activity may lead to the decrease of response at high $\mathrm{pH}$ since strongly acidic and alkaline environments result in the denaturation of HRP [48]. The optimum response was achieved in $\mathrm{pH}$. The acquired $\mathrm{pH}$ is correspondent with the isoelectric point of peroxide enzyme, but to ensure a higher sensitivity and stability of the biosensor, we chose a $0.1 \mathrm{M}$ PBS (pH 7.0, containing $0.1 \mathrm{M} \mathrm{KCl}$ ) for the determination of hydrogen peroxide, the optimum $\mathrm{pH}$ value for living organisms. The effect of operating potential on the response and background current of the biosensor was studied, and an optimum signal-to-noise $(\mathrm{S} / \mathrm{N})$ ratio was obtained at $-180 \mathrm{mV}$ (vs. $\mathrm{Ag} / \mathrm{AgCl}$ pseudoreference electrode), which was selected as the applied potential for amperometric measurements. The electrocatalytic activity of enzymes is strongly dependent on temperature; hence the effect of temperature on the biosensor response was studied. With an increase in temperature, the response time decreased because of the increased activity of the enzyme at higher temperatures. In order to maintain the stability and reproducibility of the biosensor for a long time, we thus chose room temperature as the operating temperature in our experiments.

\subsection{Amperometric Response of the Biosensor}

In order to study the performance of the biosensor during the $\mathrm{H}_{2} \mathrm{O}_{2}$ detection, current-time experiments were performed. Figure 6 shows the biosensor's current-time response to successive step changes of $\mathrm{H}_{2} \mathrm{O}_{2}$ concentration under optimized experimental conditions. After stabilization of the background current, $10 \mu \mathrm{L}$ of $\mathrm{H}_{2} \mathrm{O}_{2}$ solution was successively added to the PBS (pH 7.0) buffer solution. Uponthe addition of $\mathrm{H}_{2} \mathrm{O}_{2}$ to the stirring PBS

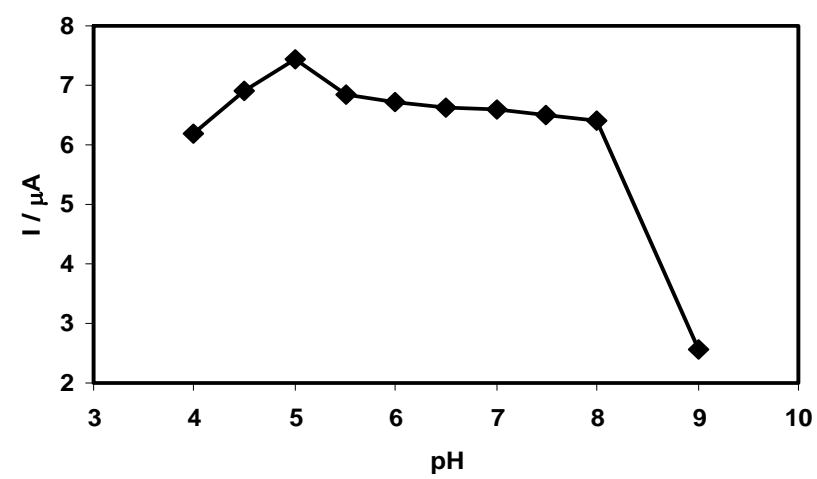

Figure 5. Effect of $\mathrm{pH}$ on the performance of HRP/titania sol-gel/graphite biosensor in $0.1 \mathrm{M}$ phosphate buffer containing $50 \mu \mathrm{M} \mathrm{H}_{2} \mathrm{O}_{2}$ at $25^{\circ} \mathrm{C}$ and Eapp $=-180 \mathrm{mV}$. 


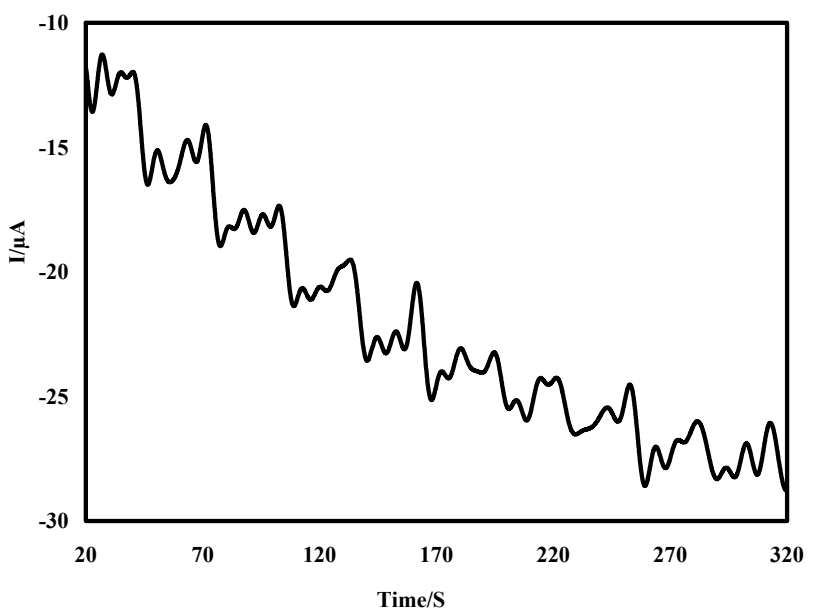

Figure 6. Amperometric response of the fabricated biosensor to successive addition of $\mathrm{H}_{2} \mathrm{O}_{2}$ in a stirred $0.1 \mathrm{M}$ PBS (pH 7.0) with an applied potential of $-0.18 \mathrm{~V}$ vs. Pseudo reference $\mathrm{Ag} / \mathrm{AgCl}$.

buffer solution, the biosensor indicated a rapid and sensitive response. The linear response of the biosensor was in the range of $10^{-5}$ to $10^{-3} \mathrm{M}$, with a detection limit of 4.5 $\times 10^{-6} \mathrm{M}$, and the acceptable response was obtained at $\mathrm{pH}=7.0$. The current responses were reproducible over the concentration range of $10^{-5}$ to $10^{-3} \mathrm{M}(\mathrm{RSD}=4.6 \%$, $\mathrm{n}=6$ ).

In Table 1 a comparison of the biosensor developed in this study with others based on HRP is shown. The comparison indicated that the porous structure of Titania solgel matrix provides an acceptable detection limit, long linearity, and high stability in comparison with other biosensors that need very expensive materials. Considering the other advantages of this biosensor, such as its simplicity of preparation, portability, and relatively low cost, this type of biosensor can be potentially commercia-lized for the detection of hydrogen peroxide.

\section{Conclusion}

This work developed a novel biosensor for hydrogen peroxide based on screen-printed electrode technology by immobilizing horseradish peroxidase (HRP) in Titania sol-gel matrix using a vapor deposition method. The suggested sol-gel method retains HRP biological activity since it provides a mild immobilization process for enzyme and a biocompatible microenvironment around the hydrogen peroxide. The porous structure of the Titania sol-gel matrix is very efficient in preventing HRP leakage out of the film, resulting in the enzyme's good loading, high catalytic activity and the biosensor's fast response rate. In contrast to official methods, simple preparation and the short time of analysis are the main advantages of this biosensor. The application developed in the current study highlights the criterion of flexibility
Table 1. Comparison of the proposed $\mathrm{H}_{2} \mathrm{O}_{2}$ biosensor with other biosensors based on HRP.

\begin{tabular}{|c|c|c|c|}
\hline Immobilization matrix & $\begin{array}{l}\text { Linear } \\
\text { range }(\mathrm{M})\end{array}$ & $\begin{array}{l}\text { Detection } \\
\text { limit }(\mathrm{M})\end{array}$ & Reference \\
\hline $\begin{array}{c}\mathrm{HRP} / \mathrm{CaCO}_{3}-\mathrm{AuNPs} \\
/ \mathrm{ATP} / \mathrm{Au}\end{array}$ & $\begin{array}{l}5 \times 10^{-7} \text { to } \\
5.2 \times 10^{-3}\end{array}$ & $1 \times 10^{-7}$ & {$[51]$} \\
\hline 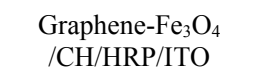 & $\begin{array}{l}5 \times 10^{-6} \text { to } \\
3.8 \times 10^{-3}\end{array}$ & $6 \times 10^{-7}$ & {$[52]$} \\
\hline $\begin{array}{l}\mathrm{Au} / \mathrm{GS} / \mathrm{HRP} \\
/ \mathrm{CS} / \mathrm{GCE}\end{array}$ & $\begin{array}{l}5 \times 10^{-6} \text { to } \\
5.1 \times 10^{-3}\end{array}$ & $1.7 \times 10^{-6}$ & {$[48]$} \\
\hline $\begin{array}{c}\text { HRP-GNPs/Thi/ } \\
\text { GNPs/MWCNTs } \\
\text {-Chit/GCE }\end{array}$ & $\begin{array}{l}5 \times 10^{-7} \\
\text { to } 1.5 \times 10^{-3}\end{array}$ & $3.75 \times 10^{-8}$ & [19] \\
\hline $\begin{array}{l}\text { MWCNTs/MG } \\
\text { /HRP/GCE }\end{array}$ & $\begin{array}{l}5 \times 10^{-7} \text { to } \\
2.0 \times 10^{-5}\end{array}$ & $5 \times 10^{-7}$ & {$[18]$} \\
\hline Con A/Au-HRP & $\begin{array}{l}5 \times 10^{-6} \text { to } \\
1.2 \times 10^{-2}\end{array}$ & $2.9 \times 10^{-6}$ & {$[53]$} \\
\hline $\begin{array}{c}\mathrm{HRP} / \text { titania } \\
\text { sol-gel/graphite }\end{array}$ & $\begin{array}{c}1 \times 10^{-5} \text { to } \\
1 \times 10^{-3}\end{array}$ & $4.5 \times 10^{-6}$ & this work \\
\hline
\end{tabular}

ATP: 4-aminothiophenol, $\mathrm{CH}$ : chitosan, ITO: indum tin oxide, GS: sulfonated graphen, GNPs: gold nanoparticles, Thi: thionine, MG: methylen green, Con A: concanavalin A.

resulting from coupling screen-printing technology with the use of a simple compound to produce biosensors.

\section{Acknowledgements}

Special thanks to Mr, Fereydoon Rasouli for his support and encouragement during this study.

\section{REFERENCES}

[1] A. L. Sanford, S. W. Morton, K. L. Whitehouse, H. M. Oara, L. Z. Lugo-Morales, J. G. Roberts and L. A. Sombers, Voltammetric Detection of Hydrogen Peroxide at Carbon Fiber Microelectrodes," Analytical Chemistry, Vol. 82, No. 12, 2010, pp. 5205-5210. http://dx.doi.org/10.1021/ac100536s

[2] C. Creanga, S. Serban, R. W. Pittson and N. El Murr, "No Calibration" Type Sensor in Routine Amperometric Biosensing-An Example of a Disposable Hydrogen Peroxide Biosensor," Biosensors-Emerging Materials and Applications, 2011, pp. 141-152.

[3] A. H. A. Al Obaidi, "Role of Airway Lactoperoxidase in Scavenging of Hydrogen Peroxide Damage in Asthma," Annals of Thoracic Medicine Vol. 2, No. 3, 2007, pp. 107-110. http://dx.doi.org/10.4103/1817-1737.33698

[4] H. L. Cai, "Hydrogen Peroxide Regulation of Endothelial Function: Origins, Mechanisms and Consequences," Cardiovascular Research, Vol. 68, No. 1, 2005, pp. 26-36. http://dx.doi.org/10.1016/j.cardiores.2005.06.021

[5] N. S. Brown and R. Bicknell, "Hypoxia and Oxidative Stress in Breast Cancer Oxidative Stress: Its Effects on the Growth, Metastatic Potential and Response to Ther- 
apy of Breast Cancer," Breast Cancer Research, Vol. 3, No. 5, 2001, pp. 323-327. http://dx.doi.org/10.1186/bcr315

[6] B. J. Tabner, O. M. A. El-Agnaf, S. Turnbull, M. J. German, K. E. Paleologou, Y. Hayashi, L. J. Cooper, N. J. Fullwood and D. Allsop, "Hydrogen Peroxide Is Generated during the Very Early Stages of Aggregation of the Amyloid Peptides Implicated in Alzheimer Disease and Familial British Dementia," Journal of Biological Chemistry, Vol. 280, No. 43, 2005, pp. 35789-35792. http://dx.doi.org/10.1074/jbc.C500238200

[7] M. Giorgio, M. Trinei, E. Migliaccio and P. G. Pelicci, "Hydrogen Peroxide: A Metabolic By-Product or a Common Mediator of Ageing Signals," Nature Reviews Molecular Cell Biology, Vol. 8, No. 9, 2007, pp. 722-728. http://dx.doi.org/10.1038/nrm2240

[8] E. S. Forzani, G. A. Rivas and V. M. Solis, Amperometric Determination of Dopamine on an Enzymatically Modified Carbon Paste Electrode," Journal of Electroanalytical chemistry, Vol. 382, No. 1-2, 1995, pp. 33-40. http://dx.doi.org/10.1016/0022-0728(94)03640-O

[9] J. Kulys, L. Gorron, E. Domingues, J. Emneus and H. Jarskog, "Electrochemical Characterization of Carbon pastes Modified with Proteins and Polycations," Journal of Electroanalytical Chemistry, Vol. 372, No. 1-2 , 1994, pp. 49-55. http://dx.doi.org/10.1016/0022-0728(93)03262-N

[10] Z. Wang, J. Yi and S. Yang, "Direct Electrochemistry and Electrocatalysis of Hemoglobin Incorporated in Composite Film Based on Diblock Weak Polyelectrolyte PHAEMA-b PDMAEMA and Multi-Walled Carbon Nanotubes," Sensors and Actuators B: Chemical, Vol. 176, 2013, pp. 211-216. http://dx.doi.org/10.1016/j.snb.2012.10.002

[11] M. C. Y. Chang, A. Pralle, E. Y. Isacoff and C. J. Chang, "A Selective, Cell-Permeable Optical Probe for Hydrogen Peroxide in Living Cells," Journal of the American Chemical Society, Vol. 126, No. 47, 2004, pp. 15392-15393. http://dx.doi.org/10.1021/ja0441716

[12] J. Li, P. K. Dasgupta and G. A. Tarver, "Pulsed Excitation Source Multiplexed Fluorometry for the Simultaneous Measurement of Multiple Analytes. Continuous Measurement of Atmospheric Hydrogen Peroxide and Methyl Hydroperoxide," Analytical Chemistry, Vol. 75, No. 5, 2003, pp. 1203-1210. http://dx.doi.org/10.1021/ac026234d

[13] M. R. Miah and T. Ohsaka, "Cathodic Detection of $\mathrm{H}_{2} \mathrm{O}_{2}$ using Iodide-Modified Gold Electrode in Alkaline Media," Analytical Chemistry, Vol. 78, No. 4, 2006, pp. 1200-1205. http://dx.doi.org/10.1021/ac0515935

[14] M. Magro, D. Baratella, N. Pianca, A. Toninello, S. Grancara, R. Zboril and F. Vianello, Electrochemical Determination of Hydrogen Peroxide Production by Isolated Mitochondria: A Novel Nanocomposite Carbon-Maghemite Nanoparticle Electrode," Sensors and Actuators B: Chemical, Vol. 176, 2013, pp. 315-322. http://dx.doi.org/10.1016/i.snb.2012.09.044

[15] E. Zapp, V. Nascimento, D. Dambrowski, A. L. Braga and I. C. Vieira, "Bio-Inspired Sensor Based on Gluta- thione Peroxidase Mimetic for Hydrogen Peroxide Detection," Sensors and Actuators B: Chemical, Vol. 176, 2013, pp. 782-788. http://dx.doi.org/10.1016/j.snb.2012.09.072

[16] K. Thenmozhi and S. S. Narayanan, "Surface Renewable Sol-Gel Composite Electrode Derived from 3-Aminopropyl Trimethoxy Silane with Covalently Immobilized Thionin," Biosensors and Bioelectronics, Vol. 23, No. 5, 2007, pp. 606-612. http://dx.doi.org/10.1016/j.bios.2007.06.003

[17] Y. Xiao, H. X. Ju and H. Y. Chen, "Hydrogen Peroxide sensor Based on Horseradish Peroxidase-Labeled Au Colloids Immobilized on Gold Electrode Surface by Cysteamine Monolayer," Analytica Chimica Acta, Vol. 391, No. 1, 1999, pp. 73-82. http://dx.doi.org/10.1016/S0003-2670(99)00196-8

[18] A. K. Upadhyay, T. W. Ting and S. M. Chen, "Amperometric Biosensor for Hydrogen Peroxide Based on Coimmobilized Horseradish Peroxidase and Methylene Green in Ormosils Matrix with Multiwalled Carbon Nanotubes," Talanta, Vol. 79, No. 1, 2009, pp. 38-45. http://dx.doi.org/10.1016/j.talanta.2009.03.010

[19] S. Li, X. Zhu, W. Zhang, G. Xie and W. Feng, "Hydrogen Peroxide Biosensor Based on Gold Nanoparticles/Thionine/Gold Nanoparticles/Multi-Walled Carbon NanotubesChitosans Composite Film-Modified Electrode," Applied Surface Science, Vol. 258, No. 7, 2012, pp. 2802-2807. http://dx.doi.org/10.1016/j.apsusc.2011.10.138

[20] I. Palchetti and M. Mascini, "Electrochemical Adsorption Technique for Immobilization of Single-Stranded Oligonucleotides onto Carbon Screen-Printed Electrodes," Topics in Current Chemistry, Vol. 261, 2006, pp. 27-43. http://dx.doi.org/10.1007/b135774

[21] T. Schüler, T. Asmus, W. Fritzsche and R. Möller, "Screen Printing as Cost-Efficient Fabrication Method for DNA-Chips with Electrical Readout for Detection of Viral DNA," Biosensors and Bioelectronics, Vol. 24, No. 7, 2009, pp. 2077-2084.

http://dx.doi.org/10.1016/j.bios.2008.10.028

[22] R. Pilloton, et al., "Screen Printing for Chemical Sensor and Biosensor Production," II Workshop on Chemical Sensors and Biosensors, Rome, Italy

[23] J. P. Hart and S. A. Wring, "Recent Developments in the Design and Application of Screen-Printed Electrochemical Sensors for Biomedical, Environmental and Industrial Analyses," Trends in Analytical Chemistry, Vol. 16, No. 2, 1997, pp. 89-103. http://dx.doi.org/10.1016/S0165-9936(96)00097-0

[24] M. A. Sirvent, A. Merkoci and S. Alegret, "Configurations Used in the Design of Screen-Printed Enzymatic Biosensors. A Review, Sensors and Actuators B: Chemical, Vol. 69, No. 1-2, 2000, pp. 153-163. http://dx.doi.org/10.1016/S0925-4005(00)00536-0

[25] T. M. Ơ Regan, M. Pravda, C. K. Ơ Sullivan and G. G. Guibault, "Development of a Disposable Immunosensor for the Detection of Human Heart Fatty-Acid Binding Protein in Human Whole Blood Using Screen-Printed Carbon Electrodes," Talanta, Vol. 57, No. 3, 2002, pp. 501-510. http://dx.doi.org/10.1016/S0039-9140(02)00047-4 
[26] J. J. Rippeth, T. D. Gibson, J. P. Hart, I. C. Harthey and G. Nelson, "Flow-Injection Detector Incorporating a ScreenPrinted Disposable Amperometric Biosensor for Monitoring Organophosphate pesticides," Analyst, Vol. 122, No. 11, 1997, pp. 1425-1430. http://dx.doi.org/10.1039/a704291d

[27] R. Kataky, R. Dell and P. K. Senanayake, "CyclodextrinModified Biosensors: Comparision of CyclodextrinLinked Forrocenes as Mediators in Sol-Gel and ScreenPrinted Formats for Sensing Acetylcholine," Analyst, Vol. 126, No. 11, 2001, pp. 2015-2019. http://dx.doi.org/10.1039/b105465c

[28] A. Avramescu, T. Noguer, M. Avramescu and J. L. Marty, "Screen-Printed Biosensors for the Control of Wine Quality Based on Lactate and Acetaldehyde Determination," Analytica Chimica Acta, Vol. 458, No. 1, 2002, pp. 203-213.

http://dx.doi.org/10.1016/S0003-2670(01)01580-X

[29] J. Wang, Q. Chen, M. Pedrero and J. M. Pingarron, "Screen-Printed Amperometric Biosensors for Glucose and Alcohols Based on Ruthenium-Dispersed Carbon Inks," Analytica Chimica Acta, Vol. 300, No. 1-3, 1995, pp. 111-116. http://dx.doi.org/10.1016/0003-2670(94)00357-R

[30] R. Gupta and N. K. Chaudhury, "Entrapment of Biomolecules in Sol-Gel Matrix for Applications in Biosensors: Problems and Future Prospects," Biosensors and Bioelectronics, Vol. 22, No. 11, 2007, pp. 2387-2399. http://dx.doi.org/10.1016/j.bios.2006.12.025

[31] T. M. Park, E. I. Iwuoha, M. R. Smyth, R. Freaney and A. J. McShane, "Sol-gel Based Amperometric Biosensor Incorporating an Osmium Redox Polymer as Mediator for Detection of L-Lactate," Talanta, Vol. 44, No. 6, 1997, pp. 973-978. http://dx.doi.org/10.1016/S0039-9140(96)02164-9

[32] U. Narang, P. N. Prasad, F. V. Bright, K. Ramanathan, N. D. Kumar, B. D. Malhotra, M. N. Kamalasanan and S. Chandra, "Glucose Biosensor Based on a Sol-Gel Derived Platform," Analytical Chemistry, Vol. 66, No. 19, 1994, pp. 3139-3144. http://dx.doi.org/10.1021/ac00091a023

[33] L. L. Hench and J. K. West, "The Sol-Gel Process," Chemical Reviews, Vol. 90, No. 1, 1990, pp. 33-72. http://dx.doi.org/10.1021/cr00099a003

[34] D. Avnir, "Organic Chemistry within Ceramic Matrices: Doped Sol-Gel Materials," Accounts of Chemical Research, Vol. 28, No. 8, 1995, pp. 328-334. http://dx.doi.org/10.1021/ar00056a002

[35] E. Llobet, P. Ivanov, X. Vilanova, J. Brezmes, J. Hubalek, K. Malysz, I. Gràcia, C. Cané and X. Correig, "ScreenPrinted Nanoparticle Tin Oxide Films for High-Yield Sensor Microsystems," Sensors and Actuators B: Chemical, Vol. 96, No. 1-2, 2003, pp. 94-104. http://dx.doi.org/10.1016/S0925-4005(03)00491-X

[36] Y. Li, W. Bu, L. Wu and C. Sun, "A New Amperometric Sensor for the Determination of Bromate, Iodate and Hydrogen Peroxide Based on Titania Sol-Gel Matrix for Immobilization of Cobalt Substituted Keggin-Type Cobalttungstate Anion by Vapor Deposition Method," Sensors and Actuators B: Chemical, Vol. 107, No. 2, 2005, pp. 921-928. http://dx.doi.org/10.1016/j.snb.2004.12.040

[37] J. H. Yu and H. X. Ju, "Amperometric Biosensor for Hydrogen Peroxide Based on Hemoglobin Entrapped in Titania Sol-Gel Film," Analytica Chimica Acta, Vol. 486, No. 2, 2003, pp. 209-216. http://dx.doi.org/10.1016/S0003-2670(03)00508-7

[38] J. H. Yu, S. Q. Liu and H. X. Ju, "Glucose Sensor for Flow Injection Analysis of Serum Glucose Based on Immobilization of Glucose Oxidase in Titania Sol-Gel Membrane," Biosensors and Bioelectronics, Vol. 19, No. 4, 2003, pp. 401-409. http://dx.doi.org/10.1016/S0956-5663(03)00199-4

[39] Z. T. Jiang and Y. M. Zuo, "Synthesis of Porous Titania Microspheres for HPLC Packings by Polymerization-Induced Colloid Aggregation (PICA)," Analytical Chemistr, Vol. 73, No. 3, 2001, pp. 686-688. http://dx.doi.org/10.1021/ac001008u

[40] T. Lopez, J. H. Ventura, R. Gomez, F. Tzompantzi, E. Sanchez, X. Bokhimi and A. Garcia, Photodecomposition of 2,4-Dinitroaniline on $\mathrm{Li} / \mathrm{TiO}_{2}$ and $\mathrm{Rb} / \mathrm{TiO}_{2}$ Nanocrystallite Sol-Gel Derived Catalysts," Journal of Molecular Catalysis A, Vol. 167, No. 1-2, 2001, pp. 101-107. http://dx.doi.org/10.1016/S1381-1169(00)00496-9

[41] E. Milella, F. Cosentino, A. Licciulli and C. Massaro, "Preparation and Characterization of Titania/Hydroxyapatite Composite Coatings Obtained by Sol-Gel Process," Biomaterials, Vol. 22, No. 11, 2001, pp. 1425-1431. http://dx.doi.org/10.1016/S0142-9612(00)00300-8

[42] J. Yu and H. Ju, Pure Organic Phase Phenol Biosensor Based on Tyrosinase Entrapped in a Vapor Deposited Titania Sol-Gel Membrane," Electroanalysis, Vol. 16, No. 16, 2004, pp. 1305-1310. http://dx.doi.org/10.1002/elan.200302951

[43] P. Kouvaris, A. Delimitis, V. Zaspalis, D. Papadopoulos, S. A. Tsipas and N. Michailidis, "Green Synthesis and Characterization of Silver Nanoparticles Produced Using Arbutus Unedo Leaf Extract," Materials Letters, Vol. 76, 2012, pp. 18-20.

http://dx.doi.org/10.1016/j.matlet.2012.02.025

[44] L. Zhang, Y. Li, L. Zhang, D. W. Li, D. Karpuzov and Y. T. Long, Electrocatalytic Oxidation of NADH on Graphene Oxide and Reduced Graphene Oxide Modified Screen-Printed Electrode," International Journal of Electrochemical Science, Vol. 6, No. 1, 2011, pp. 819-829.

[45] R. G. González, M. T. F. Abedul, A. Pernía and A. C. García, "Electrochemical Characterization of Different Screen-Printed Gold Electrodes, Electrochimica Acta, Vol. 53, No. 8, 2008, pp. 3242-3249. http://dx.doi.org/10.1016/j.electacta.2007.07.059

[46] M. Mathew and N. Sandhyarani, "A Novel Electrochemical Sensor Surface for the Detection of Hydrogen Peroxide Using Cyclic Bisureas/Gold Nanoparticle Composite," Biosensors and Bioelectronics, Vol. 28, No. 1, 2011, pp. 210-215. http://dx.doi.org/10.1016/j.bios.2011.07.020

[47] A. Ahmadalinezhad, G. Wu and A. Chen, "Mediator-Free Electrochemical Biosensor Based on Buckypaper with Enhanced Stability and Sensitivity for Glucose Detection," Biosensors and Bioelectronics, Vol. 30, No. 1, 
2011, pp. 287-293.

http://dx.doi.org/10.1016/j.bios.2011.09.030

[48] K. Zhou, Y. Zhu, X. Yang, J. Luo, C. Li and S. Luan, "A Novel Hydrogen Peroxide Biosensor Based on Au-Graphene-HRP-Chitosan Biocomposites," Electrochimica Acta, Vol. 55, No. 9, 2010, pp. 3055-3060. http://dx.doi.org/10.1016/j.electacta.2010.01.035

[49] A. K. Abelskov, A. T. Smith, C. B. Rasmussen, H. B. Dunford and K. G. Welinder, "pH-Dependence and Structural Interpretation of the Reactions of Coprinus Cinereus Peroxidase with Hydrogen Peroxide, Ferulic Acid, and 2,2'-Azinobis(3-ethyl benzthiazoline-6-sulfonic Acid)," Biochemistry, Vol. 36, No. 31, 1997, pp. 9453-9463. http://dx.doi.org/10.1021/bi970387r

[50] S. K. Arya, A. K. Prusty, S. P. Singh, P. R. Solanki, M. K. Pandey, M. Datta and B. D. Malhotra, "Cholesterol Biosensor Based on N-(2-Aminoethyl)-3-aminopropyltrimethoxysilane Self-Assembled Monolayer," Analytical
Biochemistry, Vol. 363, No. 2, 2007, pp. 210-218. http://dx.doi.org/10.1016/j.ab.2007.01.029

[51] F. Li, Y. Feng, Z. Wang, L. Yang, L. Zhuo and B. Tang, "Direct Electrochemistry of Horseradish Peroxidase Immobilized on the Layered Calcium Carbonate-Gold Nanoparticles Inorganic Hybrid Composite," Biosensors and Bioelectronics, Vol. 25, No. 10, 2010, pp. 2244-2248. http://dx.doi.org/10.1016/j.bios.2010.03.006

[52] K. Zhou, Y. Zhu, X. Yang, C. Li, "Preparation and Application of Mediator-Free $\mathrm{H}_{2} \mathrm{O}_{2}$ Biosensors of Graphene- $\mathrm{Fe}_{3} \mathrm{O}_{4}$ Composites," Electroanalysis, Vol. 23, No. 4, 2011, pp. 862-869. http://dx.doi.org/10.1002/elan.201000629

[53] G. Mengmeng, Y. Yunhui, W. Zhijie, S. Guoli and Y. Ruqin, "A Mediator-free Horseradish Peroxidase Biosensor Based on Concanavalin A," Chinese Journal of Analytical Chemistry, Vol. 34, No. 3, 2006, pp. 399-402. http://dx.doi.org/10.1016/S1872-2040(06)60021-2 